https://jurnal.unigal.ac.id/index.php/edukasi

\title{
ANALISIS SWOT PEMASARAN PRODUK PEMBIAYAAN KEPEMILIKAN EMAS DI BJB SYARIAH KANTOR CABANG PEMBANTU BANTAR KALONG
}

\author{
Oleh: \\ Joni Ahmad Mughni \\ Prodi Ekonomi Syariah Fakultas Agama Islam Universitas Siliwangi, Indonesia \\ Email: joniahmadmughni83@gmail.com \\ Sejarah Artikel: Diterima April 2019, Disetujui Mei 2019, Dipublikasikan Jini 2019
}

\begin{abstract}
ABSTRAK
Tujuan dari penelitian ini adalah untuk menganalisis analisis SWOT pemasaran produk pembiayaan kepemilikan emas di BJB Syariah KCP Bantarkalong. Dengan latar belakang masalah yakni secara umum berdasarkan data BJB Syariah KCP Bantarkalong ditemukan fakta bahwa minat masyarakat terhadap produk pembiayaan emas masih rendah. Metode penelitian yang dilakukan dalam penelitian ini adalah penelitian kualitatif, dengan menggunakan metode deskriptif. Teknik pengumpulan data dilakukan dengan observasi, wawancara, dan analisis berbagai dokumen yang berkaitan dengan judul yang diteliti. Hasil penelitian ini menunjukan bahwa berdasarkan hasil EFAS (Eksternal Factors Analysis Summary) dan IFAS (Internal Factors Analysis Summary) analisis SWOT pemasaran produk PKE BJBS KCP Bantarkalong ini memiliki total nilai skor masing-masing 1,75 dan 2,45. Berdasarkan Matriks Grand Strategy maka diketahui skor EFAS dan IFAS bertemu di kuadran I. Sehingga tampak bahwa strategi yang sesuai bagi pemasaran produk PKE BJBS KCP Bantarkalong adalah strategi pertumbuhan. Artinya, perusahaan atau lembaga dapat melakukan perluasan usaha dengan menambah SDM yang berkualitas untuk dapat fokus melakukan pemasaran PKE di BJBS KCP Bantarkalong.
\end{abstract}

Kata Kunci: Pemasaran Produk, Pembiayaan Kepemilikan Emas, Investasi

\section{PENDAHULUAN}

Investasi logam mulia di Indonesia saat ini memang sedang mengalami perkembangan yang sangat pesat. Salah satu logam mulia yang sering digunakan untuk berinvestasi di Indonesia adalah emas. Emas merupakan salah satu alternatif investasi yang sangat menguntungkan (Habibah, 2017:87).

Ada dua cara kepemilikan emas untuk berinvestasi yakni dengan cara cash (tunai) dan pembiayaan. Pembelian secara tunai adalah pembelian barang dagang (dalam hal ini emas) yang dilakukan dengan kas/setara kas pada saat transaksi dilakukan. Sedangkan Pembiayaan Kepemilikan Emas (PKE) pembiayaan untuk kepemilikan emas dengan menggunakan akad murabahah (Surat Edaran BI 2018).

Salah satu Bank Syariah yang memberikan fasilitas Pembiayaan Kepemilikan Emas adalah BJB Syariah.BJB Syariah (BJBS) adalah salah satu bank umum yang menjalankan operasional bank berdasarkan prinsip syariah.
Produk Pembiayaan Kepemilikan Emas (PKE) di BJB Syariah sendiri mulai direalease pada tahun 2016. Produk PKE di BJB Syariah dimaksudkan untuk menyimpan dana investasi jangka panjang dalam bentuk emas, yang mana ini merupakan langkah bijak dalam mengelola suatu dana investasi. Karena harga emas cenderung tidak mengalami pergerakan harga yang drastis dan kebal akan inflasi. Alhasil investasi emas memiliki risiko kerugian sangat rendah. Terlebih emas tidak mengenal pergeseran kualitas.

Berdasarkan data di BJB Syariah KCP Bantarkalong ditemukan fakta bahwa minat masyarakat terhadap produk pembiayaan emas ini masih rendah. Data tersebut menunjukan bahwa BJB Syariah KCP Bantarkalong pada tahun 2016 tepatnya setahun setelah pembentukan PKE, tidak ada nasabah yang mengikuti atau mengambil PKE di BJB Syariah KCP Bantarkalong. Namun, barulah pada tahun 2017 ada 4 orang nasabah yang mengikuti 
pembiayaan kepemilikan emas tersebut. Kemudian disusul pada tahun 2018 dengan jumlah nasabah PKE menjadi sebanyak 7 orang (wawancara dengan salah satu karyawan BJBS KCP Bantarkalong pada bulan Agustus 2018). Untuk lebih jelasnya peneliti menyajikan data jumlah nasabah PKE di BJBS KCP Bantarkalong pada Tahun 2016-2018 dalam tabel sebagai berikut:

Tabel 1

Jumlah Nasabah PKE BJBS KCP Bantarkalong Tahun 2016-2018

\begin{tabular}{ccc} 
No & Tahun & Jumlah Nasabah \\
\hline 1 & 2016 & 0 \\
2 & 2017 & 5 \\
3 & 2018 & 7
\end{tabular}

Untuk menganalisis masalah dalam pemasaran produk PKE di BJB Syariah KCP Bantarkalong peneliti menggunakan analisis SWOT, dimana faktor internal akan mempengaruhi terbentuknya strength dan weakness ( $\mathrm{S}$ dan $\mathrm{W})$, yang menyangkut dengan kondisi di dalam lembaga perbankan. Sedangkan faktor eksternal akan mempengaruhi terbentuknya opportunities dan threats $(\mathrm{O}$ dan T) (Rangkuti, 2017: 20-21).

\section{METODE PENELITIAN \\ Metode Penelitian}

Metode penelitian yang dilakukan dalam penelitian ini adalah penelitian kualitatif, dengan menggunakan metode deskriptif. Penelitian kualitatif adalah penelitian yang pemecahan masalahnya menggunakan data empiris atau sebuah proses inquiry yang menyelidiki masalah-masalah sosial dan kemanusiaan dengan tradisi metodologi yang berbeda. Peneliti membangun sebuah gambaran yang kompleks dan holistic, menganalisa kata-kata, melaporkan pandangan atau opini para informan, dan keseluruhan studi berlangsung dalam latar situasi alamiah wajar (natural setting) (Masyhuri, 2011: 25).

\section{Sumber Penelitian}

Sumber data dalam penelitian ini berupa sumber data primer dan sumber data sekunder yang berasal dari para informan yang memberikan informasi sesuai dengan kebutuhan peneliti.

\section{Teknik Pengumpulan Data}

Teknik pengumpulandata dalam penelitian ini melalui observasi, wawancara dan dokumentasi.

\section{Instrumen Penelitian}

Dalam penelitian kualitatif, instrumen utamanya adalah peneliti itu sendiri, namun selanjutnyasetelah fokus penelitian menjadi jelas, maka kemungkinan akan dikembangkan intrumen penelitian lainnya.

\section{Uji Kredibilitas Data}

Uji kredibilitas data dalam penelitian ini menggunakan ketekunan pengamatan, trianggulasi, dan kecukupan referensi.

\section{Teknik Analisis Data}

Dalam teknik analisis data peneliti menggunakan alat analisis berupa analisis SWOT dengan matriks EFAS (Exsternal Factors Analysis Summary)dan IFAS (Internal Factors Analysis Summary).

\section{HASIL PENELITIAN DAN PEMBAHASAN}

BJB Syariah (BJBS) adalah salah satu bank umum yang menjalankan operasional bank berdasarkan prinsip syariah. Salah satu produk yang hadir di BJBS adalah produk Pembiayaan Kepemilikan Emas (PKE) iB Maslahah yang tergolong dalam salah satu produk pembiayaan konsumtif. Pembiayaan Kepemilikan Emas iB Maslahah sendiri adalah produk pembiayaan dimana Bank memberikan fasilitas pembiayaan kepada Nasabah untuk melakukan pembelian barang berupa emas batangan/lantakan atau perhiasan, dengan cara diangsur.

Dari hasil penelitian yang dilakukan oleh peneliti di BJBS KCP Bantarkalong, selanjutnya akan dirumuskan dalam analisis SWOT pemasaran produk Pembiayaan Kepemilikan Emas.

Dari hasil analisis SWOT terhadap Produk PKEtersebut, kemudian akan peneliti sajikan dalam matriks EFAS (Eksternal Factors Analysis Summary) dan IFAS (Internal Factors Analysis Summary). Hasil dari analysis SWOT adalah identifikasi distinctive competencies perusahaan/lembaga yang berasal dari sumber daya dan kemampuan internal yang dimiliki perusahaan serta sejumlah peluang yang selama ini belum dimanfaatkan, seperti akibat adanya kekurangan dalam kemampuan internal perusahaan/lembaga (Solihin, 2015: 164). 
Tabel 2

Matrik Faktor Strategi Eksternal

\begin{tabular}{|c|c|c|c|c|}
\hline Faktor Strategi Eksternal & Bobot & Rating & $\begin{array}{c}\text { Bobot } x \\
\text { Rating }\end{array}$ & Komentar \\
\hline \\
\hline $\begin{array}{l}\text { 1. Belum mampu mengoptimalkan minat } \\
\text { masyarakat terhadap investasi emas yang } \\
\text { lebih tinggi dibandingkan dengan investasi } \\
\text { lainnya. }\end{array}$ & 0,20 & 3 & 0,60 & $\begin{array}{l}\text { Rendahnya minat } \\
\text { masyarakat terhadap } \\
\text { PKE }\end{array}$ \\
\hline $\begin{array}{l}\text { 2. Belum mampu memanfaatkan kondisi } \\
\text { masyarakat Indonesia yang mayoritasnya } \\
\text { adalah muslim. }\end{array}$ & 0,20 & 3 & 0,60 & Jumlah nasabah \\
\hline $\begin{array}{l}\text { 3. Belum mampu memanfaatkan adanya } \\
\text { produk PKE sejenis di Bank lain khususnya } \\
\text { produk PKE di Perbankan Syariah. }\end{array}$ & 0,15 & 2 & 0,30 & $\begin{array}{l}\text { Sosialisasi dan Informasi } \\
\text { kepada masyarakat }\end{array}$ \\
\hline \multicolumn{5}{|l|}{ ANCAMAN: } \\
\hline $\begin{array}{l}\text { 1. Akad PKE di lembaga non-perbankan } \\
\text { syariah. }\end{array}$ & 0,20 & 2 & 0,40 & Perlu hati-hati \\
\hline $\begin{array}{l}\text { 2. Paradigma masyarakat yang masih } \\
\text { menyamakan sistem Syariah dengan } \\
\text { Konvensional. }\end{array}$ & 0,20 & 2 & 0,40 & Perlu hati-hati \\
\hline $\begin{array}{l}\text { 3. Keadaan perekonomian Indonesia yang } \\
\text { buruk (sedang tidak baik). }\end{array}$ & 0,05 & 3 & 0.15 & Diperhatikan \\
\hline
\end{tabular}

Tabel 3

Matrik Faktor Strategi Internal

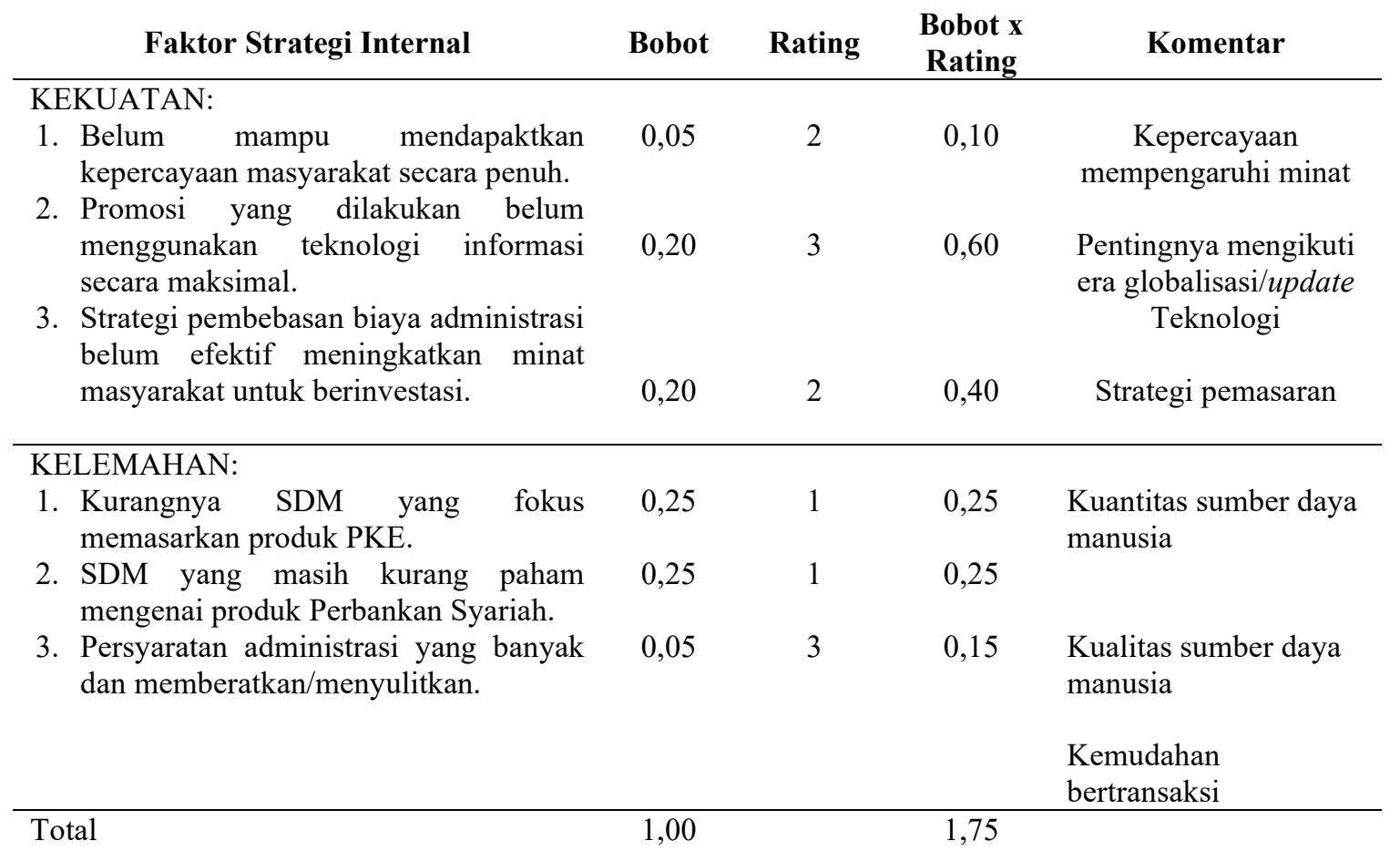

Dari data tersebut diperoleh hasil dari bobot $\mathrm{x}$ reting IFAS adalah 1,75 dan hasil bobot $\mathrm{x}$ rating EFAS adalah 2,45. Kemudian, berdasarkan hasil EFAS dan IFAS diatas maka langkah selanjutnya lembaga dapat melakukan arah formulasi strategi dengan menggunakan matriks TOWS atau SWOT. 
Strategi atau pemecahan masalah yang dapat dihasilkan dari beberapa kombinasi antara unsur-unsur EFAS dan IFAS tersebut adalah sebagai berikut (Solihin, 2015: 169):

Tabel 4

Matrik SWOT

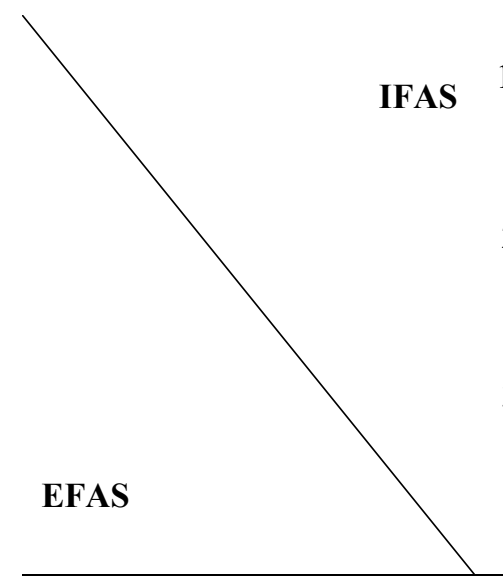

\section{OPPORTUNITIES (O)}

1. Belum mampu mengoptimalkan minat masyarakat terhadap investasi emas yang lebih tinggi dibandingkan dengan investasi lainnya.

2. Belum mampu memanfaatkan kondisi masyarakat Indonesia yang mayoritasnya adalah muslim.

3. Belum mampu memanfaatkan adanya produk PKE sejenis di Bank lain khususnya produk PKE di Perbankan Syariah.

\section{THREATS (T)}

1. Produk PKE di lembaga non-perbankan syariah.

2. Paradigma masyarakat yang masih menyamakan sistem Syariah dengan Konvensional.

3. Keadaan perekonomian Indonesia yang buruk (sedang tidak baik).

\section{STRENGTHS (S)}

1. Belum mendapaktkan kepercayaan masyarakat secara penuh .

2. Promosi yang dilakukan belum menggunakan teknologi informasi secara maksimal.

3. Strategi pembebasan biaya administrasi belum efektif meningkatkan minat masyarakat untuk berinvestasi.

\section{STRATEGI SO}

1. Meninjau kembali sumber daya manusia (SDM) yang ada di Lembaga.

2. Melakukan promosi atau pemasaran produk PKE dengan memanfaatkan produk PKE sejenis di perbankan lain dan memaksimalkan penggunaan internet khususnya sosial media untuk mengiklankan produk PKE di BJBS KCP Bantarkalong.

3. Melakukan pemasaran keluar wilayah Bantarkalong

STRATEGI ST
1. Meningkatkan citra lembaga khususnya perbankan syariah.

2. Melakukan promosi sekaligus edukasi.

3. Melakukan pembebasan seluruh biaya administrasi.

\section{WEAKNESSES (W)}

1. Kurangnya SDM yang fokus memasarkan produk PKE.

2. SDM yang masih kurang paham mengenai produk Perbankan Syariah.

3. Persyaratan administrasi yang banyak dan memberatkan/menyulitkan.

\section{STRATEGI WO}

1. Menyederhanakan atau memudahkan persyaratan pendaftaran produk PKE.

2. Melakukan pelatihan dan pendidikan bagi Karyawan BJBS KCP Bantarkalong.

3. Melakukan survei lapangan mengenai minat PKE.

Dari pemaparan di atas dapat diketahui 4 set kemungkinan strategi yang dapat diterapkan oleh BJBS KCP Bantarkalong dalam Produk Pembiayaan Kepemilikan Emasnya. Ke 4 set strategi tersebut memungkinkan untuk membantu BJBS KCP Bantarkalong khususnya dalam produk PKE untuk meningkatkan minat nasabah maupun mayarakat.

Setelah diketahui beberapa opsi strategi berdasarkan matriks SWOT dan total nilai skor IFAS = 1,75 dan EFAS 2,45. Maka langkah selanjutnya adalah penentuan matriks grand strategy. Langkah ini dilakukan mengetahui strategi atau pemecahan masalah yang manakah yang akan diambil. Idea dasar dari strategi ini adalah pemilihan dua variabel sentral di dalam proes penentuan; (1) Penentuan tujuan 
utama grand strategy; (2) Memilih faktor-faktor internal atau eksternal untuk pertumbuhan atau profitabilitas (Rangkuti, 2017: 99-100).

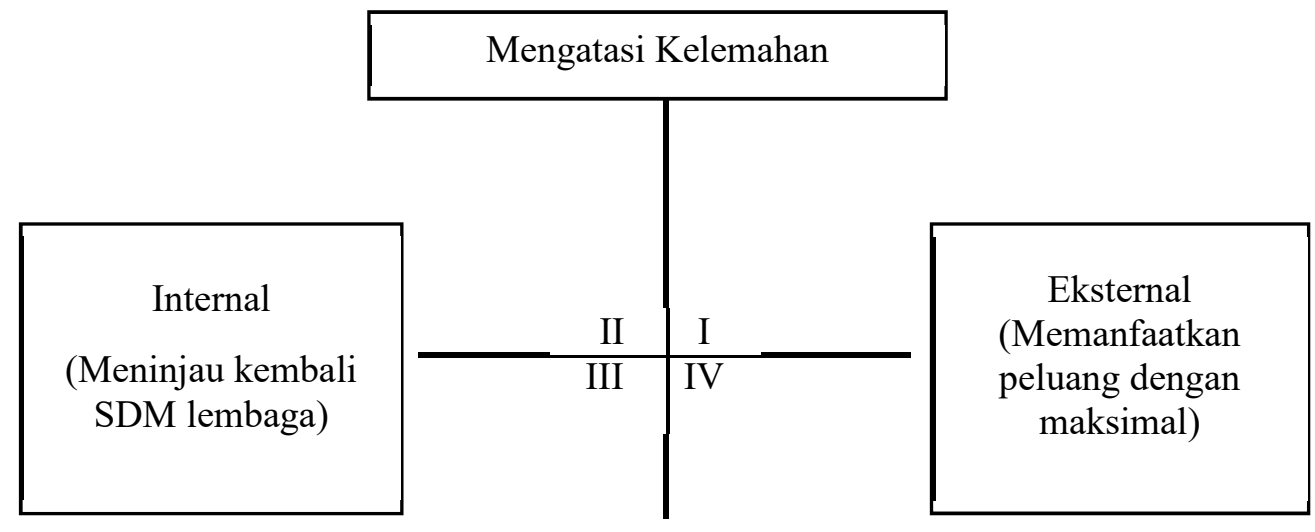

\author{
Keterangan : \\ Kuadran I \\ Kuadran II \\ : Integrasi Vertikal dan Diversifikasi Konglomerat. \\ Kuadran III \\ : Turnaround dan Likuidasi \\ Kuadran IV \\ : Konsentrasi, Pengembangan Produk \& Pasar, \\ dan Melakukan Inovasi. \\ : Integrasi Horizontal, Diversifikasi Konsentrik, dan \\ Joint Venture.
}

Berdasarkan Matriks Grand Strategy tersebut dengan total nilai skor IFAS $=1,75$ dan EFAS 2,45 maka diketahui skor EFAS dan IFAS bertemu di kuadran I. Sehingga tampak bahwa strategi yang sesuai bagi pemasaran produk PKE di BJBS KCP Bantarkalong adalah strategi pertumbuhan.

Dimana keterangan kuadran I adalah integrasi vertikal dan diversifikasi konglomerat. Artinya, perusahaan atau lembaga dapat melakukan perluasan usaha dengan menambah SDM yang berkualitas untuk dapat fokus melakukan pemasaran PKE di BJBS KCP Bantarkalong. Selain itu, lembaga atau pegawai bank juga dapat melakukan akuisisi (melakukan pembelian) emas yang akan diinvestasikan sehingga dengan adanya investor yang melakukan produk PKE, diharapkan ini akan menumbuhkan minat masyarakat atau nasabah lainnya dalam melakukan Pembiayaan Kepemilikan Emas. Apalagi jika pihak bank (karyawan bank) sesudah merasakan sendiri manfaat dari PKE di BJBS KCP Bantarkalong tersebut, sehingga ini dapat dijadikan sebagai motivasi dan dapat menumbuhkan rasa kepercayaan bagi yang lainnya kepada pihak BJBS KCP Bantarkalong.

\section{KESIMPULAN \\ Simpulan}

Berdasarkan hasil EFAS (Eksternal Factors Analysis Summary) dan IFAS (Internal Factors Analysis Summary) analisis SWOT pemaaran produk PKE BJBS KCP Bantarkalong memiliki total nilai skor masing-masing 1,75 dan 2,45 . Kemudian hasil ini disusun dalam Matriks SWOT yang menghasilkan empat set pertimbangan strategi untuk pemecahan masalah dalam pemasaran produk PKE di BJBS KCP Bantarkalong.

EFAS dan IFAS bertemu di kuadran I. Sehingga tampak bahwa strategi yang sesuai bagi pemasaran produk PKE BJBS KCP Bantarkalong adalah strategi pertumbuhan. Artinya, perusahaan atau lembaga dapat melakukan perluasan usaha dengan menambah SDM yang berkualitas untuk dapat fokus melakukan pemasaran PKE di BJBS KCP Bantarkalong. Selain itu, lembaga atau pegawai bank juga dapat melakukan akuisisi (melakukan pembelian) emas yang akan diinvestasikan.

\section{Saran}

Produk Pembiayaan Kepemiikan Emas merupakan salah satu produk pembiayaan konsumtif yang hadir di BJBS KCP Bantarkalong. Hadirnya produk pembiayaan ini diharapkan dapat meningkatkan minat 
masyarakat terhadap dunia investasi dan sebagai salah satu solusi mempermudah masyarakat dalam meenuhi keinginannya dalam hal kepemilikan emas. Mengingat banyak sekali manfaat yang akan didapatkan oleh nasabah apabila mereka mengambil produk PKE tersebut. Sehingga dalam hal pemasaran produk PKE haruslah dioptimalkan. Tentunya dalam upaya pengoptimalisasiannya juga dibuthkan beberapa alternative strategi yang efektif dan efisien, yang dijalankan oleh berbagai pihak dengan optimal. Untuk itu dibutuhkan kerja sama dan koordinasi yang baik dari berbagai pihak khususnya pihak internal BJBS KCP Bantarkalong.

\section{DAFTAR PUSTAKA}

Habibah, Nunung Uswatun. (Januari, 2017). "Perkembangan Gadai Emas Ke Investasi Emas Pada Pegadaian Syariah". Amwaluna, Vol. 1 No. 1.

Hasil wawancara dengan karyawan BJB Syariah KCP Bantarkalong pada bulan November 2018

Ibrahim. (2015). Metodologi Penelitian Kualitatif. Bandung: Alfabeta CV.

Masyhuri \& Zainudin. (2011). Metode penelitian Pendekatan Praktis dan Aplikatif Edisi Revisi. Bandung: PT Refika Aditama.

Nisak, Zahrotun. (2014). "Analisis SWOT Untuk Menentukan Strategi Kompetitif. Jurnal EKBIS, Fakultas Ekonomi: Universitas Islam Lamongan.

Rangkuti, Freddy. (2017). Analisis SWOT: Teknik Membedah Kasus Bisnis. Jaakarta: Kompas Gramedia.

Solihin, Ismail. (2015). Managent Strategic. Jakarta: Erlangga.

Surat Edaran Bank Indonesia Nomor 10/31/Dpbs Tanggal 07 Oktober 2018 Perihal Produk Bank Syariah Dan Unit Usaha Syariah 